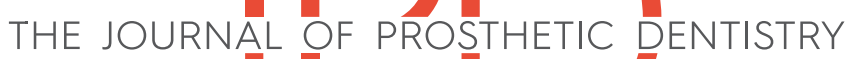

RESEARCH AND EDUCATION

\section{Evaluation of the effect of an offset implant configuration in the posterior maxilla with external hexagon implant platform: A 3-dimensional finite element analysis}

\author{
Victor Eduardo de Souza Batista, MSc, ${ }^{a}$ Fellippo Ramos Verri, PhD, ${ }^{b}$ Daniel Augusto de Faria Almeida, PhD, \\ Joel Ferreira Santiago Junior, PhD, ${ }^{d}$ Cleidiel Aparecido Araújo Lemos, MSc, and \\ Eduardo Piza Pellizzer, PhD $^{f}$
}

Before dental implants, removable partial denture prostheses were considered the best treatment option for extensive partial edentulism with no prospective terminal abutment tooth, such as in Kennedy class I and II scenarios. ${ }^{1}$ However, dental implants offer a viable treatment option for managing clinical scenarios of both partial and complete edentulism. ${ }^{2,3}$

Different ways of rehabilitating patients with extensive partial edentulism with no prospective terminal abutment tooth have been described, mainly in the context of planning the placement of 3 implants to support the replacement of missing premolars and a molar, or a missing second premolar and 2 molars. ${ }^{4,5}$ For these restorations, there are 2 ways to

\begin{abstract}
Statement of problem. Slight offset of the central implant in 3-unit implant-supported prostheses has been reported to improve biomechanical behavior. However, studies that assessed the effects of an offset implant configuration in the posterior maxilla are scarce.

Purpose. The purpose of this 3-dimensional (3D) finite element analysis was to assess the effects of splinting in 3-unit implant-supported prostheses with varying implant positions (straight-line or offset configuration) in terms of the stress/strain distribution on bone tissue and the stress distribution on abutment screws.

Material and methods. Three 3D models were used to simulate a posterior maxilla bone block (type IV): straight-line implants supporting single crowns (model M1), straight-line implants supporting 3-unit splinted fixed dental prosthesis (model M2), and an offset implant configuration supporting 3-unit splinted fixed dental prosthesis (model M3). The applied forces were $400 \mathrm{~N}$ axially and $200 \mathrm{~N}$ obliquely. The type of implant platform simulated was an external hexagon. von Mises stress on the abutment screws was measured, and the maximum principal stress and microstrain values were used to perform cortical bone tissue analysis. Analysis of variance (ANOVA) and the Tukey honest significant differences post hoc test were used to determine the significance of the results and interactions among the main variables $(\alpha=.05)$.
\end{abstract}

Results. In all models, oblique load increased the stress on abutment screws and bone tissue and the microstrain on bone tissue. Model M3 decreased the stress concentration on the abutment screws and bone tissue. With regard to microstrain distribution, model M3 had the smallest values, and $\mathrm{M} 1$ and $\mathrm{M} 2$ had similar values.

Conclusions. Splinting associated with an offset implant configuration was effective for decreasing the stress on abutment screws and bone tissue and the microstrain on bone tissue. (J Prosthet Dent 2017;118:363-371)

\footnotetext{
Supported by grants 2012/24893-1 and 2015/07383-8 from the São Paulo Research Foundation, Brazil.

${ }^{a}$ Graduate student, Graduate Program in Dentistry, Department of Dental Materials and Prosthodontics, Araçatuba Dental School, São Paulo State University, São Paulo, Brazil.

${ }^{\mathrm{b}}$ Assistant Professor, Department of Dental Materials and Prosthodontics, Araçatuba Dental School, São Paulo State University, São Paulo, Brazil.

${ }^{\mathrm{c} A d j u n c t ~ P r o f e s s o r, ~ S c h o o l ~ o f ~ D e n t i s t r y, ~ F e d e r a l ~ U n i v e r s i t y ~ o f ~ A l f e n a s, ~ M i n a s ~ G e r a i s, ~ B r a z i l . ~}$

${ }^{\mathrm{d}}$ Assistant Professor, Department of Health Sciences, University of Sacred Heart, São Paulo, Brazil.

eGraduate student, Graduate Program in Dentistry, Department of Dental Materials and Prosthodontics, Araçatuba Dental School, São Paulo State University, São Paulo, Brazil.

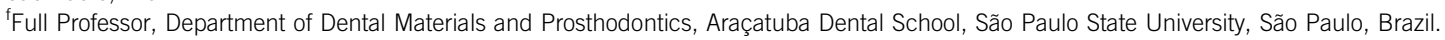




\section{Clinical Implications}

Splinting with an offset implant configuration improves the biomechanical behavior of 3-unit fixed dental prostheses. This type of implant placement may represent a good treatment option for the rehabilitation of the posterior maxilla.

place the implants: in a straight-line configuration or in an offset configuration. ${ }^{4,6}$ Furthermore, the prostheses may be single units or splinted as a fixed dental prosthesis (FDP). ${ }^{5}$ Weinberg and Kruger $^{7}$ suggested that slight displacement of the central implant relative to the lingual or buccal area (an offset configuration) could improve the biomechanical behavior of the restoration, and since that report, the effects of implant position have been evaluated in different biomechanical studies. ${ }^{8-10}$ However, no consensus has been reached on the advantages of using an offset configuration, although some biomechanical studies have shown a slight improvement in bone stress distribution, mainly under oblique load. ${ }^{4}$ Furthermore, the authors are unaware of published studies that have evaluated the biomechanical behavior of the offset implant placement on the posterior maxilla. Additionally, hygiene access may be impaired when an offset implant is placed because of the modification of the cervical contours of the prosthesis.

Clinicians are unclear as to whether the crowns in the posterior area should be splinted or not. ${ }^{11,12}$ Some authors have suggested that, compared with single-unit crowns, a splinted prosthesis offers better stress distribution, ${ }^{5,13}$ particularly in low-quality bone. ${ }^{14}$ However, the use of single-unit crowns (not splinted) enables patients to maintain optimal oral hygiene, facilitates a better restoration fit, and is associated with better restoration emergence profiles and cervical contours. ${ }^{15,16}$

Bone quality may affect the survival rate of dental implants, as type IV bone (Lekholm and Zarb classification) is associated with a lower survival rate than type I, II, or III. 3,17 Therefore, the biomechanical behavior of different prostheses is particularly important for rehabilitating the posterior maxilla area in type IV bone, particularly in patients missing premolars and a molar or a second premolar and 2 molars, where 3 implants are placed.

Finite element analysis (FEA) enables simulation of a situation that would be impossible to perform in a clinical study. ${ }^{18}$ Additionally, mathematical calculations can be used to predict unfavorable biomechanical situations for bone tissue and prosthetic components. ${ }^{19}$ Therefore, FEA is considered a useful tool for studying stress distribution in implantology. ${ }^{19,20}$

The purpose of the present study was to assess the effects of splinting in 3-unit implant-supported prostheses
Table 1. Description of models

\begin{tabular}{|c|c|c|c|c|c|}
\hline Implant & Model & $\begin{array}{l}\text { Implant } \\
\text { Position }\end{array}$ & $\begin{array}{l}\text { Crown } \\
\text { Design }\end{array}$ & Load & $\begin{array}{c}\text { No. of } \\
\text { Nodes/ } \\
\text { Elements }\end{array}$ \\
\hline \multirow[t]{5}{*}{$\mathrm{EH}(4.0 \times 10 \mathrm{~mm})$} & M1 & Straight-line & $\begin{array}{l}\text { Single-unit } \\
\text { crown }\end{array}$ & Axial & $\begin{array}{c}1238344 / \\
890640\end{array}$ \\
\hline & & & & Oblique & \\
\hline & M2 & Straight-line & $\begin{array}{l}\text { Splinted } \\
\text { crowns }\end{array}$ & Axial & $\begin{array}{c}1399415 / \\
581493\end{array}$ \\
\hline & & & & Oblique & \\
\hline & M3 & Offset & $\begin{array}{l}\text { Splinted } \\
\text { crowns }\end{array}$ & Axial & $\begin{array}{l}953290 / \\
591677\end{array}$ \\
\hline
\end{tabular}

EH, external hexagon; M1, straight-line implants supporting single crowns; M2, straightline implants supporting 3-unit splinted fixed dental prosthesis; M3, offset implant configuration supporting 3-unit splinted fixed dental prosthesis.

with varied implant positions (a straight-line or offset configuration) on the stress/strain distribution on bone tissue and the stress distribution on abutment screws using 3-dimensional (3D) FEA. The null hypothesis was that these implant positions would not generate any significant differences in the biomechanical behavior of the models analyzed.

\section{MATERIAL AND METHODS}

Three 3D models were created to represent clinical situations (Table 1). Each model simulated a bone block (type IV) of the posterior maxillary segment (first premolar to right first molar) by varying the splinting and arrangement of the implants as follows: straight-line implants supporting single crowns (model M1), straight-line implants supporting 3-unit splinted FDP (model M2), and an offset implant configuration supporting 3-unit splinted FDP (model M3). The bone section was composed of trabecular bone in the center, surrounded by a 1-mm cortical bone layer obtained by decomposition of a computed tomography (sagittal section) of the first premolar to the right first molar with software (InVesalius; CTI Renato Archer) and surface simplification performed using software (Rhinoceros 3D v4.0; NURBS modeling for Windows [Microsoft Corp]; Robert McNeel \& Associates).

The implant design was obtained by simplification of a $4.0 \times 10 \mathrm{~mm}$ external hexagonal design (Conexão Sistemas de Protese Ltd). The positions of the implants in the straight-line models were simulated at a distance of $7 \mathrm{~mm}$ between the premolars, which was measured from center to center and a distance of $8.75 \mathrm{~mm}$ between the premolar and first molar. ${ }^{21}$ In the offset implant configuration model, the intermediate implant, relative to the second premolar, was displaced by 1.5 $\mathrm{mm}$ in the buccal direction. ${ }^{21-24}$ Furthermore, simulation of the customized implant abutment was the same in all models. Screw-retained metal-ceramic crowns were simulated in straight-line models, with single-unit 
Table 2. Mechanical properties applied in finite element analysis

\begin{tabular}{lccc}
\hline Structure & Elastic Modulus $(\mathbf{G P a})$ & Poisson Ratio $(v)$ & References \\
\hline Trabecular bone with low density (type IV bone) & 1.10 & 0.30 & Sevimay et al. ${ }^{28} 2005$ \\
\hline Cortical bone & 13.7 & 0.30 & Sertgöz \\
\hline Titanium & 110.0 & 0.35 & Sertgöz $z^{27} 1997$ \\
\hline Ni-Cr alloy & 206.0 & 0.33 & Anusavice and Hojjatie $^{25} 1987$ \\
\hline Feldspathic porcelain & 82.8 & 0.35 & Eraslan et al $^{26} 2005$ \\
\hline
\end{tabular}
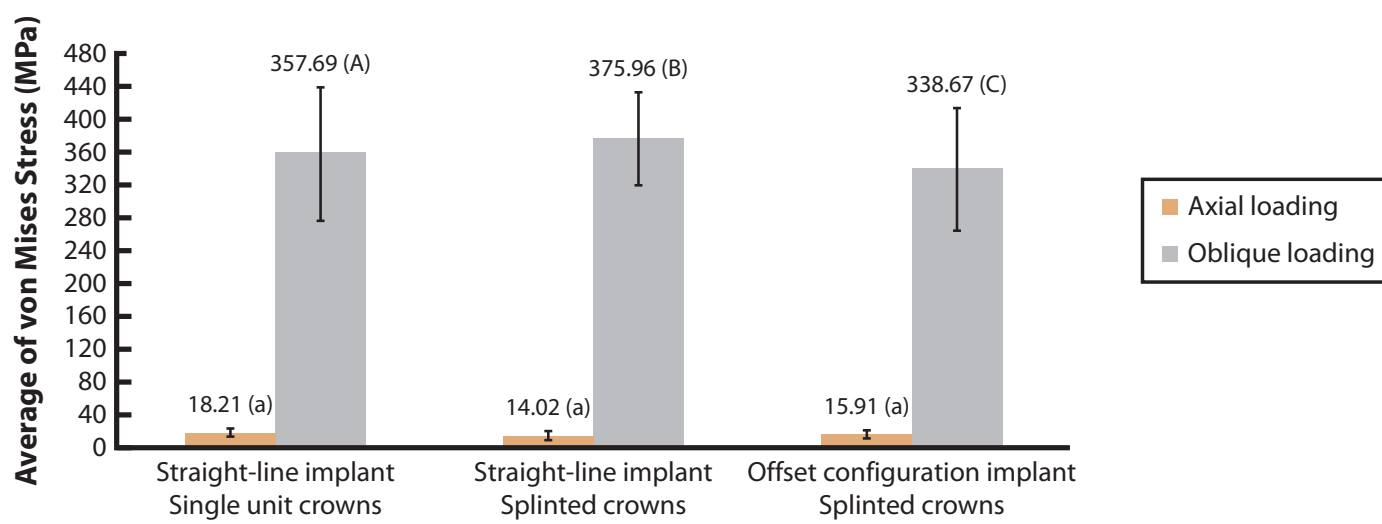

Model

Figure 1. Mean \pm SD values of abutment screw von Mises stress under axial and oblique loads. Different uppercase and lowercase letters indicate significant differences $(P<.05)$.

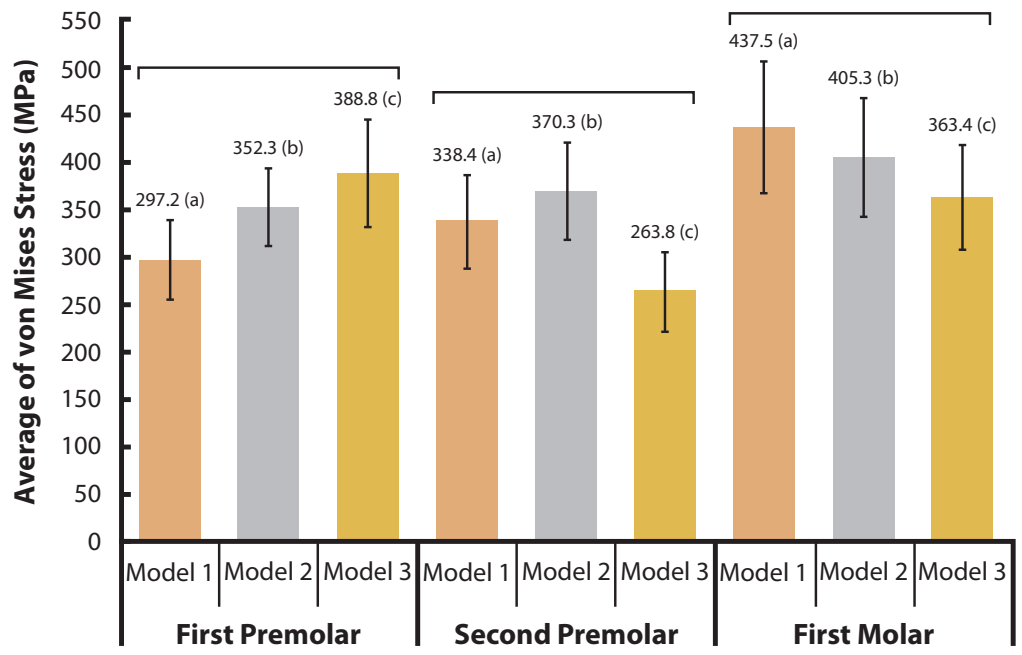

Figure 2. Mean \pm SD values of abutment screw von Mises stress for each implant under oblique load. Different lowercase letters indicate significant differences $(P<.05)$.

and splinted FDPs. Implants, abutments, crowns, and abutment screws were simplified using design (SolidWorks 2010; SolidWorks Corp) and 3D computer graphics software (Rhinoceros v4.0; NURBS modeling for Windows [Microsoft Corp]; Robert McNeel \& Associates). Finally, all geometries were exported to discretization in the finite element program (FEMAP v11.1.2; Siemens PLM Software Inc).

The FEMAP 11.1.2 software was used to generate 3D models of the preprocessing and postprocessing stages.
Meshes with tetrahedral parabolic solid elements were generated in the preprocessing stage. Moreover, the mechanical properties of each simulated material were attributed to the meshes using values from previous studies (Table 2). ${ }^{25-28}$ All materials were considered isotropic, homogeneous, and linearly elastic. The numbers of nodes and elements are presented in Table 1. During the postprocessing stage, maps created from mathematical calculations generated by FEA solver software (NEi Nastran v11.1; Noran Engineering Inc) 
Table 3. Abutment screw von Mises stress means $\pm S D$

\begin{tabular}{|c|c|c|c|}
\hline Model & Loading & Implant Position* & Mean \pm SD \\
\hline M1 & Axial & $1^{\circ} \mathrm{PM}$ & $11.57 \pm 1.31$ \\
\hline M1 & & $2^{\circ} \mathrm{PM}$ & $21.07 \pm 2.39$ \\
\hline M1 & & $1^{\circ} \mathrm{M}$ & $22.01 \pm 2.20$ \\
\hline M2 & & $1^{\circ} \mathrm{PM}$ & $7.85 \pm 0.71$ \\
\hline M2 & & $2^{\circ} \mathrm{PM}$ & $14.02 \pm 1.46$ \\
\hline M2 & & $1^{\circ} \mathrm{M}$ & $20.31 \pm 2.41$ \\
\hline M3 & & $1^{\circ} \mathrm{PM}$ & $12.02 \pm 1.74$ \\
\hline M3 & & $2^{\circ} \mathrm{PM}$ & $13.20 \pm 0.96$ \\
\hline M3 & & $1^{\circ} \mathrm{M}$ & $22.53 \pm 2.29$ \\
\hline M1 & Oblique & $1^{\circ} \mathrm{PM}$ & $297.15 \pm 41.97$ \\
\hline M1 & & $2^{\circ} \mathrm{PM}$ & $338.41 \pm 49.25$ \\
\hline M1 & & $1^{\circ} \mathrm{M}$ & $437.53 \pm 69.95$ \\
\hline M2 & & $1^{\circ} \mathrm{PM}$ & $352.30 \pm 41.12$ \\
\hline M2 & & $2^{\circ} \mathrm{PM}$ & $370.32 \pm 51.14$ \\
\hline M2 & & $1^{\circ} \mathrm{M}$ & $405.28 \pm 62.46$ \\
\hline M3 & & $1^{\circ} \mathrm{PM}$ & $388.85 \pm 55.69$ \\
\hline M3 & & $2^{\circ} \mathrm{PM}$ & $263.80 \pm 41.60$ \\
\hline M3 & & $1^{\circ} \mathrm{M}$ & $363.38 \pm 54.71$ \\
\hline
\end{tabular}

M1, straight-line implants supporting single crowns; M2, straight-line implants supporting 3-unit splinted fixed dental prosthesis; M3, offset implant configuration supporting 3 -unit splinted fixed dental prosthesis. * $1^{\circ} \mathrm{PM}$, first premolar; $2^{\circ} \mathrm{PM}$, second premolar; $1^{\circ} \mathrm{M}$, first molar.

were read and plotted, as described in further detail subsequently.

In the preprocessing stage, the abutment/implant contact was assumed to be symmetrical, and all other contacts were assumed to be symmetrically welded. The boundary conditions were fixed in axes $\mathrm{x}, \mathrm{y}$, and $\mathrm{z}$, simulating fixation of the maxilla to the facial skeleton. The applied forces were $400 \mathrm{~N}$ axially, with $50 \mathrm{~N}$ at each cusp tip and $200 \mathrm{~N}$ obliquely, with $50 \mathrm{~N}$ at each lingual cusp tip.

All FEAs were performed using FEA solver software (NEi Nastran v11.1; Noran Engineering Inc). The processing analysis was performed using a workstation (Hewlett-Packard Development Co) with the following characteristics: Intel Xeon Processor X3470, 16 GB RAM, and $2 \mathrm{~TB}$ of storage. Results were exported to FEA software (FEMAP v11.1.2; Siemens PLM Software Inc) to create graphic visualizations of stress/strain on bone tissue and abutment screws. von Mises analysis was used to assess the stress distribution in abutment screws, and quantitative analysis was performed as it is adequate for the analysis of ductile material. ${ }^{19}$

Maximum principal stress was used to assess the stress on cortical bone tissue by means of qualitative analysis, as it provides compression (negative values) and tension (positive values) values. ${ }^{20,29}$ Additionally, microstrain $(\mu \varepsilon)$ analysis was used to assess deformation around the cortical bone tissue. ${ }^{19}$ Both quantitative and qualitative analyses were performed to obtain values to compare with the resorption risk scale described by Frost. ${ }^{30}$ The unit of measure used for von Mises stress and the maximum principal stress was megapascal (MPa), whereas microstrain was determined by a deformation unit and thus is dimensionless.

The quantitative data pertaining to stress on abutment screws were analyzed using 2-way analysis of variance (ANOVA), followed by the Tukey honest significant differences post hoc test $(\alpha=.05)$. The quantitative data pertaining to microstrain on bone tissue were analyzed using 3-way ANOVA, followed by the Tukey honest significant differences post hoc test. Statistical analysis was performed using statistical software (Sigma Plot v12.0; Systat Software Inc).

\section{RESULTS}

von Mises stress values were similar in all models under axial load (M1 versus M2: $P=.755$; M1 versus M3: $P=.918$; M3 versus M2: $P=.946$ ) (Fig. 1). Compared with axial load, oblique load increased the stress in all models $(P<.001)$ (Fig. 1). In this context, an offset implant configuration with splinting (M3) decreased the stress on abutment screws (M3 versus M1, $P=.003$; M3 versus $M 2, P<.001$ ) (Fig. 1). Furthermore, splinting had the beneficial effect of dissipating the stress on the abutment screws used to retain the molar crown to the other abutment screws (Fig. 2), although on average, M2 exhibited significantly more stress than M1 (M1 versus M2: $P=.005$ ) (Fig. 1), see also mean and standard deviation values for von Mises stress on abutment screws in Table 3.

An offset implant configuration associated with splinting (M3) caused changes in the stress distribution pattern (Fig. 3). The highest area of compression and tension stresses was observed in the first molar region in M3 compared with M1 and M2 under axial load. Compared with M1 under oblique load, M2 and M3 exhibited a modified pattern of stress distribution. An offset implant configuration associated with splinting (M3) decreased the tension stress area in the lingual region (the first molar), whereas for $\mathrm{M} 1$ and $\mathrm{M} 2$, the tension stress area extended to the superior portion of the cortical bone tissue with a higher stress area (13.33 $\mathrm{MPa}$ to $22.33 \mathrm{MPa}$ ) in the first molar for M1 (Fig. 4). Furthermore, M3 had a higher tension stress area in the lingual region of the first premolar.

M3 exhibited the lowest microstrain values under axial load (M1 versus M3, $P<.001$; M2 versus M3, $P=.006$ ) (Figs. 5, 6). M1 and M2 exhibited similar biomechanical behavior $(P=.669)$.

Compared with axial load, oblique load caused a larger area of microstrain in the buccal region of the cortical bone in all models $(P<.001)$ (Fig. 7). In this context, M1 and M2 had similar biomechanical behavior $(P=.284)$, with a slight increase in microstrain for M1, and the smallest microstrain values were observed in M3 (M1 

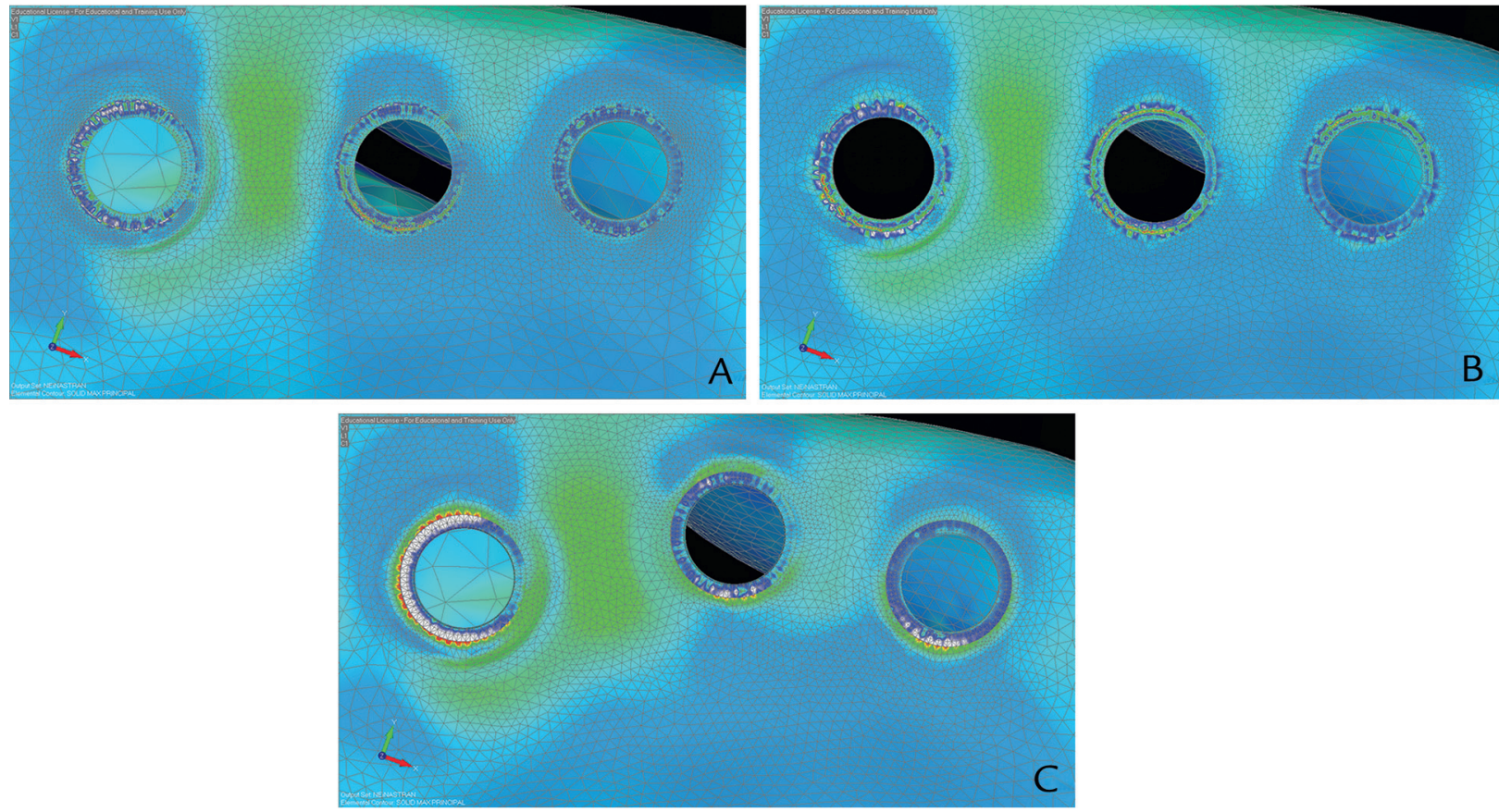

Figure 3. Maximum principal stress on cortical bone; axial load, occlusal view. A, Model 1, straight-line implants supporting single crowns. B, Model 2, straight-line implants supporting 3-unit splinted fixed dental prosthesis. C, Model 3, offset implant configuration supporting 3-unit splinted fixed dental prosthesis.
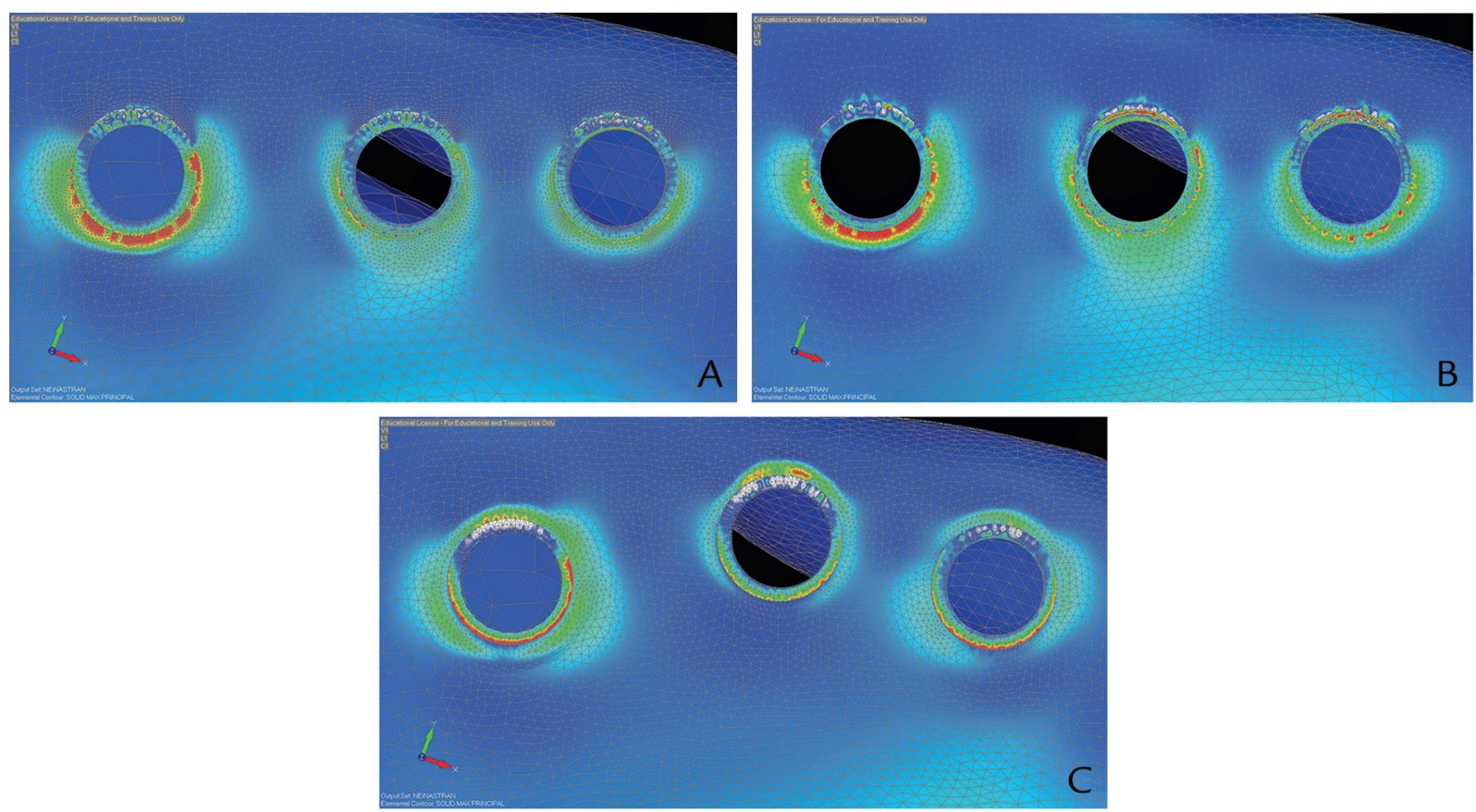

Figure 4. Maximum principal stress on cortical bone; oblique load, occlusal view. A, Model 1, straight-line implants supporting single crowns. B, Model 2, straight-line implants supporting 3-unit splinted fixed dental prosthesis. C, Model 3, offset implant configuration supporting 3-unit splinted fixed dental prosthesis. 

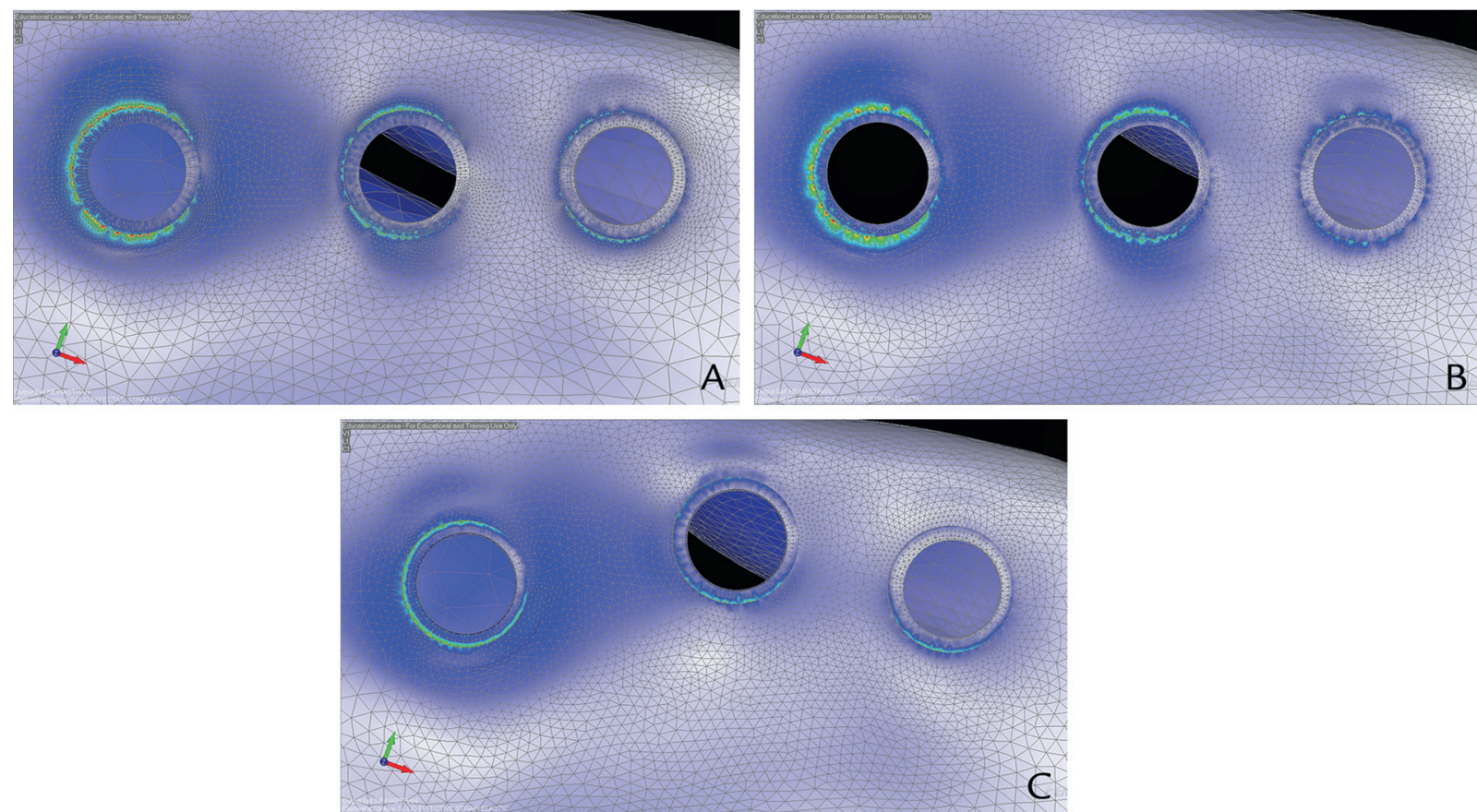

Figure 5. Microstrain on cortical bone; axial load, occlusal view. A, Model 1, straight-line implants supporting single crowns. B, Model 2, straight-line implants supporting 3-unit splinted fixed dental prosthesis. C, Model 3, offset implant configuration supporting 3-unit splinted fixed dental prosthesis.

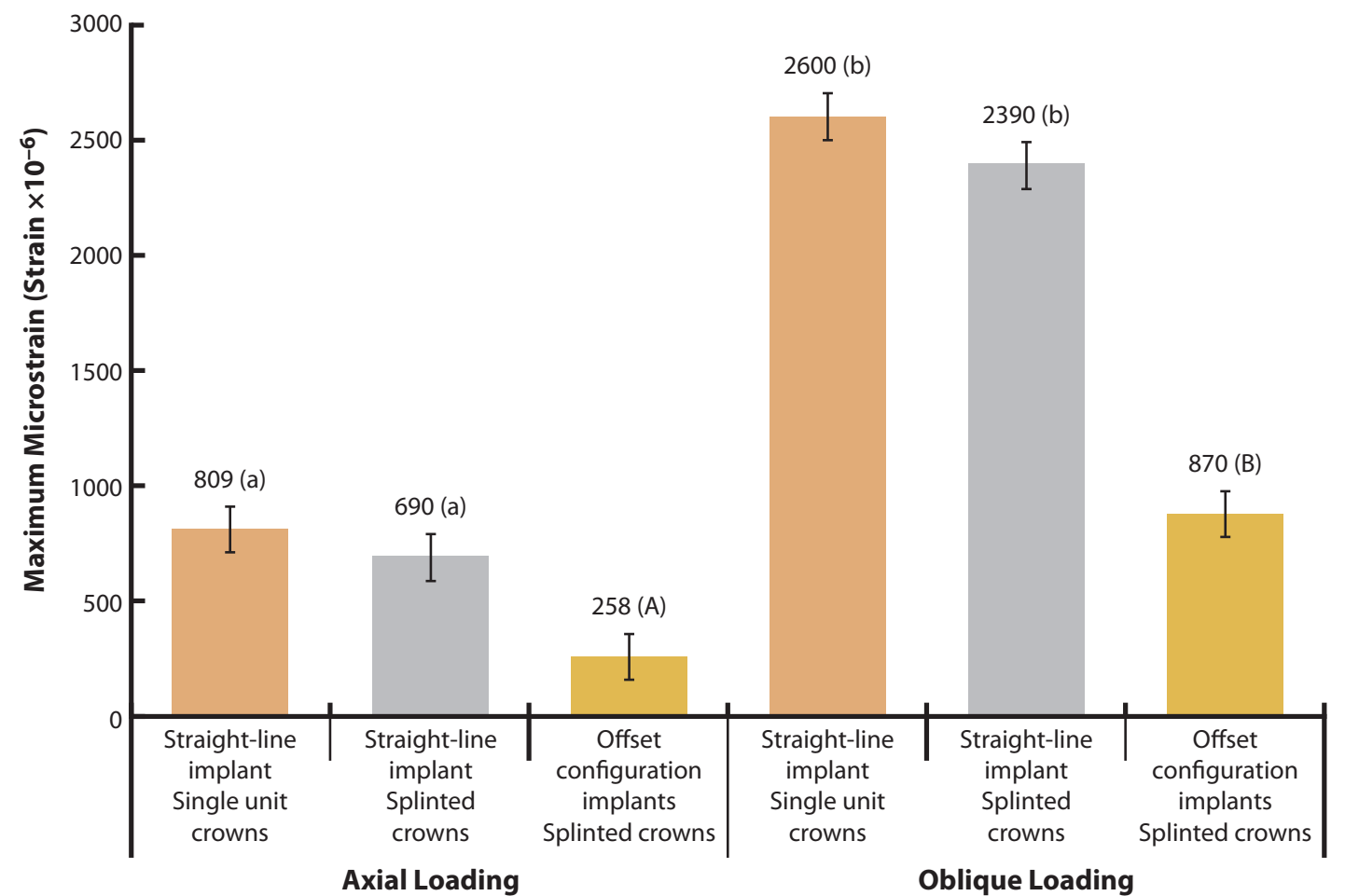

Figure 6. Mean \pm SD values for microstrain on cortical bone tissue under axial and oblique load. Different uppercase and lowercase letters indicate significant differences $(P<.05)$. 

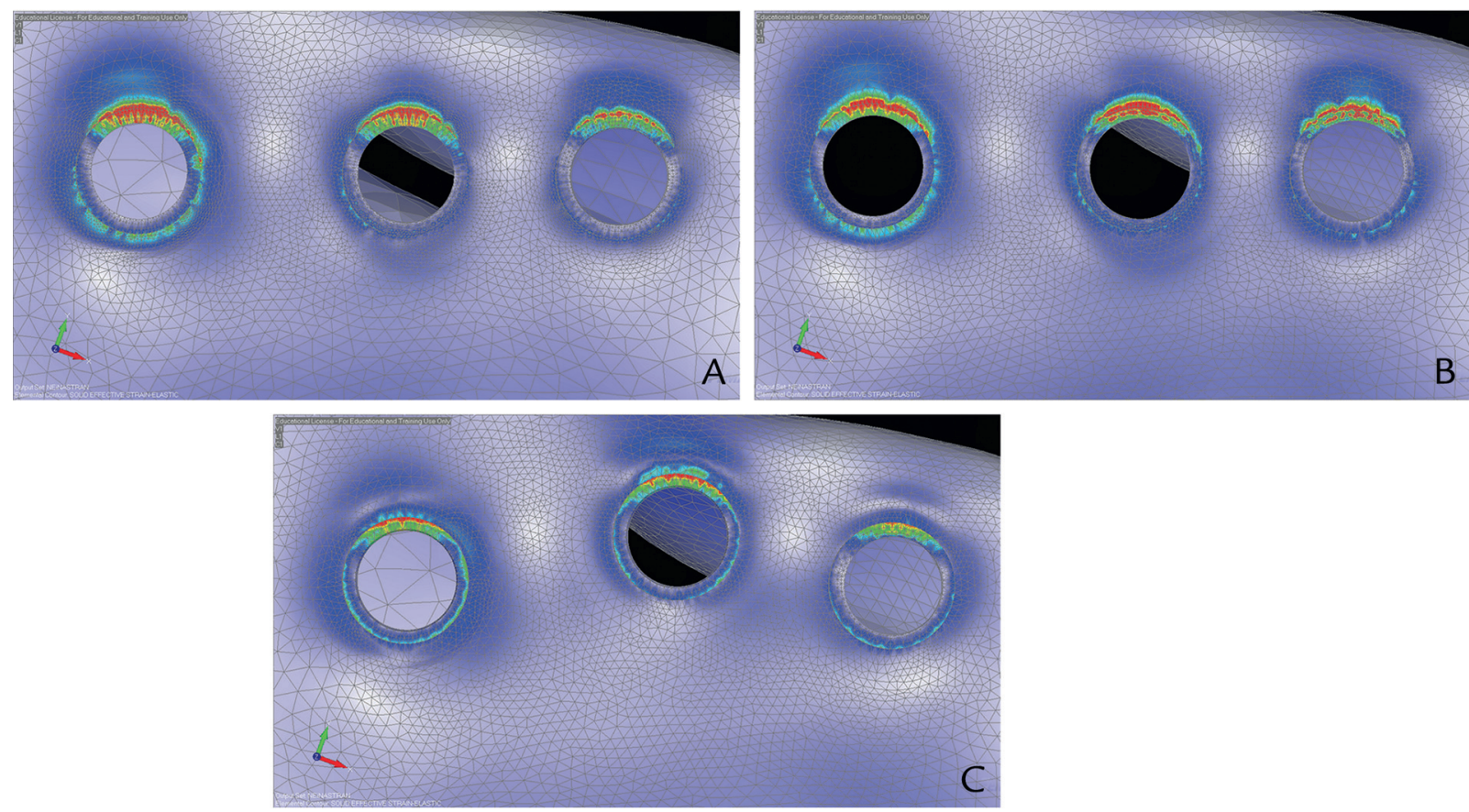

Figure 7. Microstrain on cortical bone; oblique load, occlusal view. A, Model 1, straight-line implants supporting single crowns. B, Model 2, straight-line implants supporting 3-unit splinted fixed dental prosthesis. C, Model 3, offset implant configuration supporting 3-unit splinted fixed dental prosthesis.

versus M3, P<.001; M2 versus M3, P<.001) (Figs. 6, 7). Mean values for cortical bone tissue, microstrain, under axial load are shown in Table 4 and in Table 5 under oblique load.

\section{DISCUSSION}

The null hypothesis was rejected because splinting associated with an offset implant configuration had a different biomechanical behavior in the analyzed models.

In the present study, the bone microstrain values under axial load were within the proposed limits of the mechanostat hypothesis described by Frost ${ }^{30}(3000 \mu \varepsilon)$; however, these values exceeded the bone's operational microdamage threshold range, reaching more than 6000 $\mu \varepsilon .^{30}$ In the present study, bone tissue was considered isotropic, linear, and homogeneous under static linear FEA, which is similar to previous studies, ${ }^{31,32}$ and these factors might have contributed to these high values. Thus, the data obtained in this study should be seen as representing unfavorable clinical outcomes and should be cautiously extrapolated to the clinical setting.

Oblique load increased the stress on abutment screws and stress/strain on bone tissue. This is consistent with the findings of recent studies that have reported increases in stress at the implant/abutment interface, $^{19}$ abutment screw, ${ }^{32}$ and bone tissue ${ }^{29,20}$ under oblique loads. The results of this study indicated a beneficial effect of splinting when associated with an offset implant configuration to reduce overload, mainly on the prosthetic screws. Thus, abutment screw loosening and/or fracture is less likely when splinting is performed in the tripoidal position (M3), a desirable situation in rehabilitation with external hexagon implants.

Regarding the stress and strain distribution on cortical bone tissue, rehabilitation of the posterior maxilla with single crowns (M1) exhibited similar results compared with straight-line splinted FDPs (M2), consistent with the findings of Mendonça et $\mathrm{al}^{11}{ }^{11}$ who reported similar marginal bone loss between single and splinted crowns between 3 and 16 years. In contrast, Nissan et $\mathrm{al}^{33}$ suggested that splinting may provide favorable biomechanical behavior but only for short implants. Therefore, the similar biomechanical effects on the cortical bone tissue observed for single crowns (M1) and straight-line splinted FDPs (M2) in the present study could be justified by the use of a conventional length $(10 \mathrm{~mm})$. It has been suggested that the effect of splinting is more beneficial to the stress distribution on bone tissue when it is possible to plan the use of longer length implants associated with short implants.

In the current study, the offset implant configuration decreased the stress on abutment screws and the microstrain on cortical bone tissue around the implants. Some previous studies have reported the advantages of using the offset implant configuration to decrease stress on bone around implants, $8,24,34$ but the authors are 
Table 4. Cortical bone tissue microstrain under axial load means $\pm S D$

\begin{tabular}{|c|c|c|c|}
\hline Model & Implant Position & Region & Mean \pm SD \\
\hline \multirow[t]{12}{*}{ M1 } & $1^{\circ} \mathrm{PM}$ & Buccal & $503 \pm 101$ \\
\hline & & Mesial & $272 \pm 106$ \\
\hline & & Lingual & $895 \pm 187$ \\
\hline & & Distal & $395 \pm 160$ \\
\hline & $2^{\circ} \mathrm{PM}$ & Buccal & $1120 \pm 262$ \\
\hline & & Mesial & $85.2 \pm 22$ \\
\hline & & Lingual & $876 \pm 285$ \\
\hline & & Distal & $577 \pm 210$ \\
\hline & $1^{\circ} \mathrm{M}$ & Buccal & $1940 \pm 422$ \\
\hline & & Mesial & $262 \pm 68$ \\
\hline & & Lingual & $1380 \pm 673$ \\
\hline & & Distal & $1480 \pm 617$ \\
\hline \multirow[t]{12}{*}{ M2 } & $1^{\circ} \mathrm{PM}$ & Buccal & $563 \pm 129$ \\
\hline & & Mesial & $258 \pm 88$ \\
\hline & & Lingual & $585 \pm 158$ \\
\hline & & Distal & $263 \pm 88$ \\
\hline & $2^{\circ} \mathrm{PM}$ & Buccal & $993 \pm 163$ \\
\hline & & Mesial & $189 \pm 53$ \\
\hline & & Lingual & $945 \pm 157$ \\
\hline & & Distal & $445 \pm 146$ \\
\hline & $1^{\circ} \mathrm{M}$ & Buccal & $1500 \pm 276$ \\
\hline & & Mesial & $375 \pm 82$ \\
\hline & & Lingual & $1230 \pm 325$ \\
\hline & & Distal & $1200 \pm 378$ \\
\hline \multirow[t]{12}{*}{ M3 } & $1^{\circ} \mathrm{PM}$ & Buccal & $113 \pm 27$ \\
\hline & & Mesial & $555 \pm 64$ \\
\hline & & Lingual & $249 \pm 99$ \\
\hline & & Distal & $421 \pm 89$ \\
\hline & $2^{\circ} \mathrm{PM}$ & Buccal & $244 \pm 58$ \\
\hline & & Mesial & $298 \pm 30$ \\
\hline & & Lingual & $232 \pm 83$ \\
\hline & & Distal & $194 \pm 83$ \\
\hline & $1^{\circ} \mathrm{M}$ & Buccal & $113 \pm 27$ \\
\hline & & Mesial & $197 \pm 32$ \\
\hline & & Lingual & $255 \pm 99$ \\
\hline & & Distal & $197 \pm 25$ \\
\hline
\end{tabular}

$1^{\circ} \mathrm{PM}$, first premolar; $2^{\circ} \mathrm{PM}$, second premolar; $1^{\circ} \mathrm{M}$, first molar; $\mathrm{M} 1$, straight-line implants supporting single crowns; M2, straight-line implants supporting 3-unit splinted fixed dental prosthesis; M3, offset implant configuration supporting 3-unit splinted fixed dental prosthesis.

unaware of any studies that have evaluated the abutment screws in this context using FEA. Furthermore, bone availability is an essential factor when the offset implant configuration is used. Finally, randomized controlled trials are necessary to confirm the advantages of using this implant position.

The investigation of only 1 offset distance from the central implant $(1.5 \mathrm{~mm})$ is a limitation of the present study. Sütpideler et $\mathrm{al}^{24}$ suggested that a greater distance from the central position of the implant is more beneficial in terms of stress distribution on the bone tissue; however, that study did not use dental implants placed in the maxilla. This variable should be evaluated in further studies.

Several studies have evaluated the offset implant configuration in mandibular bone tissue by FEA, ${ }^{10,24,35-37}$ but
Table 5. Cortical bone tissue microstrain under oblique load means \pm SD

\begin{tabular}{|c|c|c|c|}
\hline Model & Implant Position & Region & Mean \pm SD \\
\hline \multirow[t]{12}{*}{ M1 } & $1^{\circ} \mathrm{PM}$ & Buccal & $4830 \pm 1050$ \\
\hline & & Mesial & $1020 \pm 272$ \\
\hline & & Lingual & $969 \pm 154$ \\
\hline & & Distal & $759 \pm 189$ \\
\hline & $2^{\circ} \mathrm{PM}$ & Buccal & $7810 \pm 1902$ \\
\hline & & Mesial & $831 \pm 331$ \\
\hline & & Lingual & $852 \pm 222$ \\
\hline & & Distal & $1190 \pm 200$ \\
\hline & $1^{\circ} \mathrm{M}$ & Buccal & $8760 \pm 2198$ \\
\hline & & Mesial & $2960 \pm 1108$ \\
\hline & & Lingual & $2030 \pm 864$ \\
\hline & & Distal & $1750 \pm 443$ \\
\hline \multirow[t]{12}{*}{ M2 } & $1^{\circ} \mathrm{PM}$ & Buccal & $6020 \pm 1671$ \\
\hline & & Mesial & $1240 \pm 221$ \\
\hline & & Lingual & $1160 \pm 248$ \\
\hline & & Distal & $719 \pm 126$ \\
\hline & $2^{\circ} \mathrm{PM}$ & Buccal & $6460 \pm 1368$ \\
\hline & & Mesial & $1130 \pm 248$ \\
\hline & & Lingual & $973 \pm 127$ \\
\hline & & Distal & $1210 \pm 199$ \\
\hline & $1^{\circ} \mathrm{M}$ & Buccal & $6690 \pm 1811$ \\
\hline & & Mesial & $1470 \pm 235$ \\
\hline & & Lingual & $1900 \pm 403$ \\
\hline & & Distal & $1410 \pm 199$ \\
\hline \multirow[t]{12}{*}{ M3 } & $1^{\circ} \mathrm{PM}$ & Buccal & $910 \pm 511$ \\
\hline & & Mesial & $890 \pm 273$ \\
\hline & & Lingual & $548 \pm 247$ \\
\hline & & Distal & $542 \pm 77$ \\
\hline & $2^{\circ} \mathrm{PM}$ & Buccal & $1590 \pm 372$ \\
\hline & & Mesial & $857 \pm 395$ \\
\hline & & Lingual & $264 \pm 178$ \\
\hline & & Distal & $940 \pm 405$ \\
\hline & $1^{\circ} \mathrm{M}$ & Buccal & $1150 \pm 433$ \\
\hline & & Mesial & $1130 \pm 382$ \\
\hline & & Lingual & $542 \pm 269$ \\
\hline & & Distal & $1080 \pm 393$ \\
\hline
\end{tabular}

$1^{\circ} \mathrm{PM}$, first premolar; $2^{\circ} \mathrm{PM}$, second premolar; $1^{\circ} \mathrm{M}$, first molar; $\mathrm{M} 1$, straight-line implants supporting single crowns; M2, straight-line implants supporting 3-unit splinted fixed dental prosthesis; M3, offset implant configuration supporting 3-unit splinted fixed dental prosthesis.

the authors are unaware of corresponding reports investigating the maxilla. The current study's results may promote a better understanding of this variable in poor quality bone, enabling physicians to improve rehabilitation planning involving the posterior regions of the maxilla.

\section{CONCLUSIONS}

Within the limitations of this finite element study, the following conclusions were drawn:

1. Splinting associated with an offset implant configuration was effective in decreasing the stress on abutment screws and bone tissue;

2. Splinting associated with an offset implant configuration decreased the microstrain on cortical bone tissue. 


\section{Oblique load increased the stress on abutment screws and increased the stress and strain on cortical bone tissue.}

\section{REFERENCES}

1. Zitzmann NU, Hagmann E, Weiger R. What is the prevalence of various types of prosthetic dental restorations in Europe? Clin Oral Implants Res 2007;3:20-33.

2. Gholami H, Mericske-Stern R, Kessler-Liechti G, Katsoulis J. Radiographic bone level changes of implant-supported restorations in edentulous and partially dentate patients: 5-year results. Int J Oral Maxillofac Implants 2014;29:898-904.

3. Goiato MC, dos Santos DM, Santiago JF Jr, Moreno A, Pellizzer EP. Longevity of dental implants in type IV bone: a systematic review. Int J Ora Maxillofac Surg 2014:43:1108-16.

4. Batista VE, Santiago Junior JF, Almeida DA, Lopes LF, Verri FR, Pellizzer EP The effect of offset implant configuration on bone stress distribution: a sys tematic review. J Prosthodont 2015:24:93-9.

5. Pellizzer E, Santiago Junior J, Villa L, de Souza Batista V, de Mello C, de Faria Almeida D, et al. Photoelastic stress analysis of splinted and unitary implant supported prostheses. Appl Phys B 2014:117:235-44.

6. Sato Y, Uchida K, Okuyama T, Kitagawa N. Verification of the influence of the arrangement of implants on the load distribution (a well-known figure by Rangert). J Oral Rehabil 2012;39:446-9.

7. Weinberg LA, Kruger B. An evaluation of torque (moment) on implant prosthesis with staggered buccal and lingual offset. Int J Periodontics Restorative Dent 1996;16:252-65.

8. Abreu CW, Nishioka RS, Balducci I, Consani RL. Straight and offset implan placement under axial and nonaxial loads in implant-supported prostheses: strain gauge analysis. J Prosthodont 2012;21:535-9.

9. Abu-Hammad O, Khraisat A, Dar-Odeh N, Jagger DC, Hammerle CH. The staggered installation of dental implants and its effect on bone stresses. Clin Implant Dent Relat Res 2007;9:121-7.

10. Itoh H, Caputo AA, Kuroe T, Nakahara H. Biomechanical comparison of straight and staggered implant placement configurations. Int J Periodontics Restorative Dent 2004;24:47-55.

11. Mendonça JA, Francischone CE, Senna PM, Matos de Oliveira AE, SottoMaior BS. A retrospective evaluation of the survival rates of splinted and non splinted short dental implants in posterior partially edentulous jaws. J Periodontol 2014;85:787-94.

12. Yilmaz B, Seidt JD, McGlumphy EA, Clelland NL. Comparison of strains for splinted and nonsplinted screw-retained prostheses on short implants. Int J Oral Maxillofac Implants 2011;26:1176-82.

13. Bergkvist G, Simonsson K, Rydberg K, Johansson F, Derand T. A finite element analysis of stress distribution in bone tissue surrounding uncoupled or splinted dental implants. Clin Implant Dent Relat Res 2008;10:40-6.

14. Wang TM, Leu LJ, Wang J, Lin LD. Effects of prosthesis materials and prosthesis splinting on peri-implant bone stress around implants in poor quality bone: a numeric analysis. Int J Oral Maxillofac Implants 2002;17:231-7.

15. Solnit GS, Schneider RL. An alternative to splinting multiple implants: use of the ITI system. J Prosthodont 1998:7:114-9.

16. Vázquez Álvarez R, Pérez Sayáns M, Gayoso Diz P, García García A. Factors affecting peri-implant bone loss: a post-five-year retrospective study. Clin Oral Implants Res 2015;26:1006-14.

17. Lekholm U, Zarb G. Patient selection and preparation. In: Brånemark PI Zarb GA, Albrektsson T, editors. Tissue-integrated prostheses: osseointegration in clinical dentistry. Chicago: Quintessence Publishing; 1985. p. 199-209.

18. Pesqueira AA, Goiato MC, Filho HG, Monteiro DR, Santos DM, Haddad MF, et al. Use of stress analysis methods to evaluate the biomechanics of oral rehabilitation with implants. J Oral Implantol 2014;40:217-28.

19. Ramos Verri F, Santiago Junior JF, de Faria Almeida DA, de Oliveira GB, de Souza Batista VE, Marques Honório H, et al. Biomechanical influence of crown to-implant ratio on stress distribution over internal hexagon short implant: 3-D finite element analysis with statistical test. J Biomech 2015;48:138-45.

20. Verri FR, Batista VE, Santiago JF Jr, Almeida DA, Pellizzer EP. Effect of crown-to-implant ratio on peri-implant stress: a finite element analysis. Mater Sci Eng C Mater Biol Appl 2014;45:234-40.
21. Puri N, Pradhan KL, Chandna A, Sehgal V, Gupta R. Biometric study of tooth size in normal, crowded, and spaced permanent dentitions. Am J Orthod Dentofacial Orthop 2007;132:279.e7-14.

22. Nishioka RS, de Vasconcellos LG, de Melo Nishioka LN. External hexagon and internal hexagon in straight and offset implant placement: strain gauge analysis. Implant Dent 2009;18:512-20.

23. Nishioka RS, de Vasconcellos LG, de Melo Nishioka GN. Comparative strain gauge analysis of external and internal hexagon, Morse taper, and influence of straight and offset implant configuration. Implant Dent 2011;20: e24-32.

24. Sütpideler M, Eckert SE, Zobitz M, An KN. Finite element analysis of effect of prosthesis height, angle of force application, and implant offset on supporting bone. Int J Oral Maxillofac Implants 2004;19:819-25.

25. Anusavice KJ, Hojjatie B. Stress distribution in metal-ceramic crowns with a facial porcelain maroin. J Dent Res 1987;66:1493-8.

26. Eraslan O, Sevimay M, Usumez A, Eskitascioglu G. Effects of cantilever design and material on stress distribution in fixed partial dentures-a finite element analysis. J Oral Rehabil 2005;32:273-8.

27. Sertgöz A. Finite element analysis study of the effect of superstructure material on stress distribution in an implant-supported fixed prosthesis. Int J Prosthodont 1997;10:19-27.

28. Sevimay M, Turhan F, Kilicarslan MA, Eskitascioglu G. Three-dimensiona finite element analysis of the effect of different bone quality on stress distribution in an implant-supported crown. J Prosthet Dent 2005;93:227-34.

29. Santiago Junior JF, Pellizzer EP, Verri FR, de Carvalho PS. Stress analysis in bone tissue around single implants with different diameters and veneering materials: a 3-D finite element study. Mater Sci Eng C Mater Biol Appl 2013;33:4700-14.

30. Frost HM. Bone's mechanostat: a 2003 update. Anat Rec A Discov Mol Cell Evol Biol 2003;275:1081-101.

31. de Faria Almeida DA, Pellizzer EP, Verri FR, Santiago JF Jr, de Carvalho PS. Influence of tapered and external hexagon connections on bone stresses around tilted dental implants: three-dimensional finite element method with statistical analysis. J Periodontol 2014;85:261-9.

32. Moraes SL, Pellizzer EP, Verri FR, Santiago JF Jr, Silva JV. Three-dimensional finite element analysis of stress distribution in retention screws of different crown-implant ratios. Comput Methods Biomech Biomed Engin 2015;18: 689-96.

33. Nissan I, Gross O, Ghelfan O, Priel I, Gross M, Chaushu G. The effect of splinting implant-supported restorations on stress distribution of different crown-implant ratios and crown height spaces. J Oral Maxillofac Surg 2011;69:2990-4.

34. Cehreli MC, Iplikçioğlu H, Bilir OG. The influence of the location of load transfer on strains around implants supporting four unit cement-retained fixed prostheses: in vitro evaluation of axial versus off-set load. J Oral Rehabil 2002;29:394-400.

35. Akça K, Iplikçioğlu H. Finite element stress analysis of the influence of staggered versus straight placement of dental implants. Int J Oral Maxillofac Implants 2001;16:722-30.

36. Huang HL, Lin CL, Ko CC, Chang CH, Hsu JT, Huang JS. Stress analysis of implant-supported partial prostheses in anisotropic mandibular bone: in-line versus offset placements of implants. J Oral Rehabil 2006;33: 501-8.

37. Sato Y, Shindoi N, Hosokawa R, Tsuga K, Akagawa Y. A biomechanical effect of wide implant placement and offset placement of three implants in the posterior partially edentulous region. J Oral Rehabil 2000;27:15-21.

\section{Corresponding author:}

Dr Victor Eduardo de Souza Batista

Department of Dental Materials and Prosthodontics

São Paulo State University (UNESP)

Araçatuba, São Paulo

BRAZIL

Email: victor_edsb@hotmail.com

\section{Acknowledgments}

The authors thank São Paulo Research Foundation Brazil for support, and the Renato Archer Research Center, Campinas, Sao Paulo, Brazil and Conexao Sistemas de Protese, Aruja, Sao Paulo, Brazil.

Copyright (C) 2016 by the Editorial Council for The Journal of Prosthetic Dentistry. 